UNITED STATES

DEPARTIENT OF THE INTERIOR

GEOLOGICAL SURVEY

PLAN OF STUDY FOR THE

REGIONAL AQUIFER-SYSTEM ANALYSIS,

COLUMBIA PLATEAU, WASHINGTON,

NORTHERN OREGON, AND NORTHWESTERN IDAHO

By J. J. Vaccaro

A contribution of the Regional

Aquifer-System Analysis Program

U.S. GEOLOGICAL SURVEY

Water-Resources Investigations Report 85-4151

Tacoma, Washington

1986 
UNITED STATES DEPARTIENT OF THE INTERIOR

Donald Paul Hodel, Secretary

GEOLOGICAL SURVEY

Dallas L. Peck, Director

For additional information write to:

Copies of this report

can be purchased from:

District Chief

U.S. Geological Survey

1201 Pacific Avenue - Suite 600

Open-File Services Section

Tacoma, Washington 98402-4384

Western Distribution Branch

U.S. Geological Survey

Box 25425, Federal Center

Lakewood, Colorado 80225

(Telephone: (303) 234-5888) 
Abstract--

Int roduction--

Geohydrologic setting-_-

Geology---

Aquifer system--_-_-_-_-

Surface water-_-_-_-

Water problems---

Purpose and objectives--

Scope and approach-_-

Geologic framework-_-

Geohydrologic characteristics---

Flow system--

Hydraulic characteristics--

St ream-aquifer relations---

Water budget--------

Geochemica1 framework--

Data-base management and application systems----------

Regional digital ground-water flow mode1-_-

Work elements--

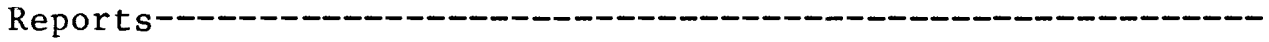

References----

\section{ILLUSTRATIONS}

FIGURE 1. Map showing location of study area------ 3

2. Generalized stratigraphy of the Columbia

Plateau-- -

3. Map showing extent of Columbia River Basalt

Group and its three major formations---_----

4. Generalized diagram of a typical flow in the

Columbia River Basalt Group-_-_-

5. Time lines for major work elements of the

Regional Aquifer System Analysis of the

Columbia River Basalt aquifer system------- 


\title{
PLAN OF STUDY FOR THE REGIONAL AQUIFER-SYSTEM \\ ANALYSIS, COLUMBIA PLATEAU, WASHINGTON, NORTHERN OREGON, AND NORTHWESTERN IDAHO
}

By J. J. Vaccaro

\begin{abstract}
In October 1983 the U.S. Geological Survey began a 4-year study of the regional aquifer system underlying the Columbia Plateau, in central and eastern Washington, northern Oregon, and northwestern Idaho as part of its Regional Aquifer-System Analysis program. The study will describe the geohydrology, geochemistry, and the regional flow system of the major formations in the Columbia River Basalt Group that underlies some 70,000 square miles of the three States. Water from the basal ts is used for municipal and industrial purposes, and most importantly for agriculture. Ground-water levels in the basalts are declining as much as 30 feet per year over large areas in response to agricultural development, and the basalts are being considered as a repository site for high-level nuclear wastes. Sound management decisions to address these problems require an understanding of the regional aquifer system.

The specific objectives of the study are 1) to describe the geologic framework of the regional aquifer system; 2) to describe its geohydrologic characteristics; 3 ) to describe the water budget of the regional aquifer system; 4) to analyze the geochemistry of the system; 5) to construct a regional data base containing geologic, hydrologic and geochemical data; and 6) to develop a regional ground-water flow model. This report describes the geohydrologic setting, problems, objectives, and approach with its associated work elements and time lines.
\end{abstract}




\section{INTRODUCTION}

The U.S. Geological Survey implemented the Regional Aquifer-System Analysis (RASA) program in 1977 to study systematically the regional ground-water systems that provide much of the Nation's water supply. The regional system underlying the Columbia Plateau was selected for inclusion in the program, and in October 1983 a 4-year study was implemented to describe the geohydrology, geochemistry, and regional flow system in the Columbia River Basalt Group of the Columbia Plateau (a flood-basalt province).

The study area consists of most of the area which is underlain by the Columbia River Basalt Group, and covers about 70,000 square miles of central and eastern Washington, northern Oregon, and part of nor thwestern Idaho (fig. 1). It is bordered on the west by the Cascade Range, on the north and east by the Rocky Mountains, and on the south by the Blue Mountains. The plateau lies entirely within the drainage of the Columbia River and includes the Snake, Spokane, Grande Ronde, John Day, Yakima, Palouse, and Deschutes Rivers, all major tributaries. The topography of the plateau is diverse, and includes the Channeled Scablands of eastern Washington, flat-to-rolling terrain in southeastern Washington, large ridges and valleys formed by anticlines and synclines in the western part of the plateau, undulating plains and terraces in the northern part, and low relief features throughout the central part of the plateau.

Precipitation varies throughout the plateau. It ranges from more than 60 inches in the Cascades on the west to nearly 27 inches in the Blue Mountains in the southeast, to less than 10 inches in the central area. The predominant economic activities are irrigated and dryland farming, and related activities. The growing season averages 185 days, but varies with latitude and elevation.

The Columbia Plateau is underlain by Miocene rocks of the Columbia River Basalt Group. The Columbia River Basalt Group comprises the regional aquifer system, which contains the major aquifers. Water from the basalt aquifers provides for most municipal, industrial, and domestic supplies and for most of the supply for irrigated lands outside the Columbia Basin Irrigation Project, the Yakima River basin, and parts of the Deschutes and Umatilla River basins (fig. 1), all of which are irrigated with surface water. Ground-water levels in the basalts are declining as much as 30 feet per year over large areas in response to agricultural development. The importance of agriculture to Washington and Oregon's economy and to the Nation's economy indicates the need to obtain a better understanding of the regional ground-water system, the quantity and quality of water available, and its interaction with the surface-water system.

This report describes the objectives, approach, and organization, and it documents the plan of study for the Columbia Plateau RASA project. The plan of study includes the major work elements and tentative time lines. Due to the nature of the investigation, the work elements and time lines cannot be fully assessed, and they will be continually updated as new information becomes available. 


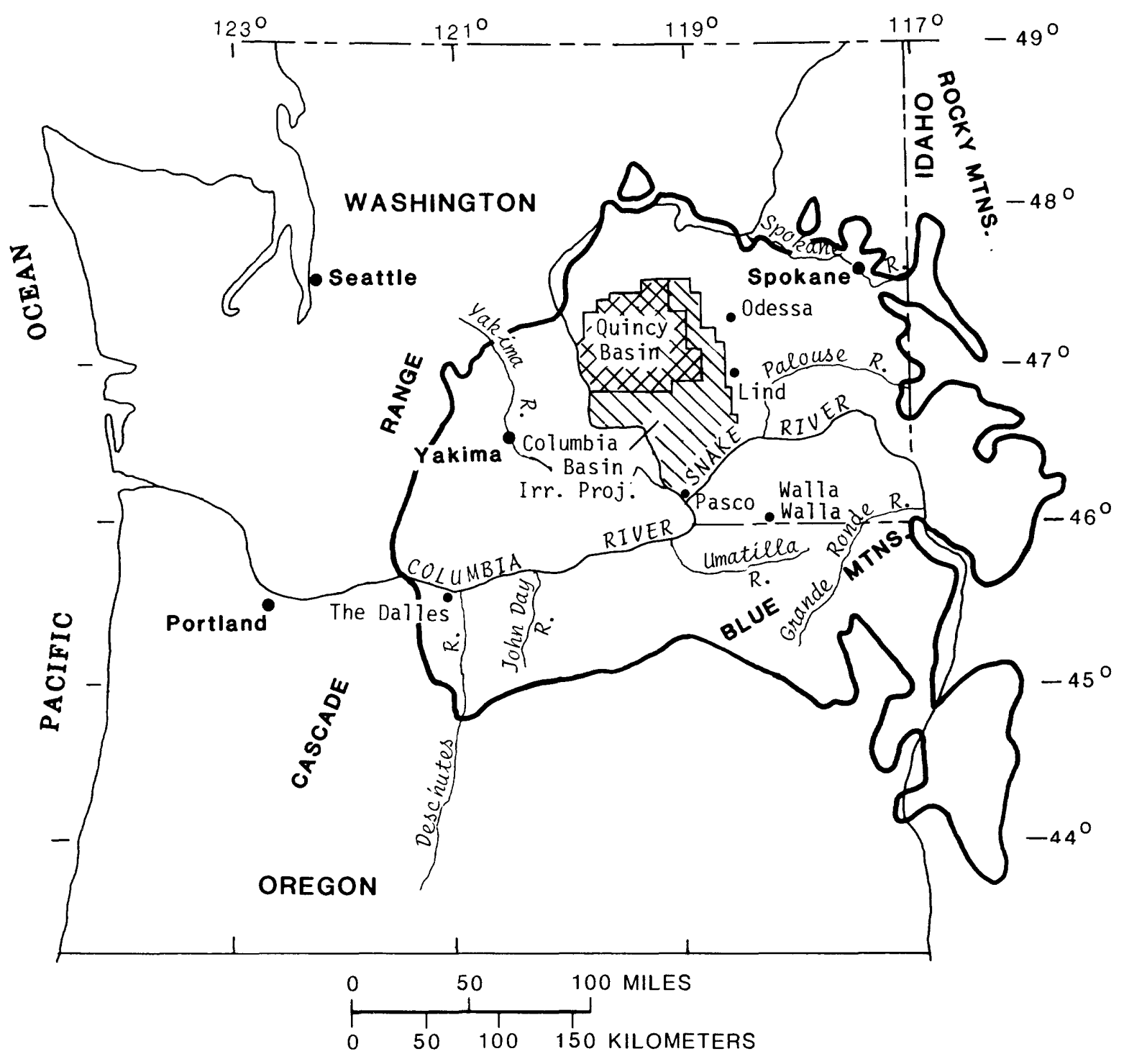

FIGURE 1.--Location of the study area. 


\section{Geology}

The basalt aquifers that underlie the Columbia Plateau are a thick and highly varied sequence of lava flows that compose the Columbia River Basalt Group. These tholeiitic flood-basalt flows have recently been given a formal stratigraphic nomenclature by Swanson and others (1979). Figure 2 shows the generalized stratigraphy of the Columbia Plateau. These flows were extruded over a period from about 16.5 to 6.0 million years before present (B.P.), with most of the flows occurring over a short period about 15 million years B.P. Less frequent eruptions occurred from 14 to 6.0 million years B.P., allowing time for erosion and deformation between eruptions (Swanson and Wright, 1978). The basaltic flows are buried deepest in the central part of the study area near Pasco, Wash., structurally the lowest part of the study area. Subsidence occurred concurrently with volcanism, and lava flows thin progressively outward from the basin axis. Where basalt abuts the older granitic and metamorphic rocks, its thickness varies greatly.

Three major formations of the Columbia River Basalt Group in order of increasing age-the Saddle Mountains, Wanapum, and Grande Ronde Basalts-will be studied (fig. 3). These formations consist of numerous flows of varied thickness and areal extent, which have been divided into stratigraphic members. Sedimentary interbeds are commonly found between major members of the Saddle Mountains and Wanapum Basalts (fig. 2) and are not so common within the Grande Ronde Basalt. Both the Mabton interbed and Vantage Member of the Ellensburg Formation are the most important stratigraphically and hydrologically in Washington, and both the Mabton interbed and the equivalent of the Beverly Member of the Ellensburg Formation, informally called the Selah interbed in this report, are most important where they occur in Oregon. These interbeds exhibit a wide variety of lithologic characteristics, and are thickest near the edges of the plateau, thin towards the center and at places they are absent (Swanson and Wright, 1978). The Beverly Member equivalent, where combined with the Mabton, is as much as 300 feet thick in the western part of the plateau in Oregon, but terminates in eastern Oregon.

The sedimentary interbeds within a basalt group can be differentiated according to whether they occur between formations (major) or lie within a basalt formation (minor). Generally, there are more minor interbeds in the younger formations. However, except for the Beverly Member, minor interbeds are usually not areally extensive or very thick. The dominant sources of the interbed material are eroded older rocks surrounding the plateau and erupting volcanos in the Cascade Range (Swanson and Wright, 1978). Some interbeds are composed of basaltic materials. The areal extent, thickness, and lithology of interbeds depends upon the time of exposure of a flow top before subsequent eruptions, the extent of a Cascade volcanic event, proximity to an older rock source and, for wind- and water-transported material, proximity to a stream. Lithology ranges from sand to a shale-like material. 
An idealized diagram of a single basalt flow is shown in figure 4. Generally, after an individual flow was extruded, the uppermost part would undergo rapid cooling and would be exposed to weathering processes. As a result, the vesicular upper part of an interflow zone is generally highly fractured or rubbly, and in many places is highly porous. The lower part of a basalt flow is denser and is characterized by entablature and colonnade jointing. Entablature jointing (small fans or slender columns with less consistent orientation or interconnectedness) develops during the cooling process or by structural deformation. In many instances, the lower part of a flow will have a section called the colonnade. The colonnade is typified by vertical joints formed during cooling either when the flow was extruded over a cool surface or when a flow came into contact with an aqueous solution. 


\begin{tabular}{|c|c|c|c|c|}
\hline & $\begin{array}{l}\text { Quaternary } \\
\text { basalt }\end{array}$ & $\begin{array}{l}\text { (glaciofluvial, fluvial, lacustrine, } \\
\text { eolian, and ash fall materials) }\end{array}$ & $\begin{array}{r}\text { Holocene and } \\
\text { Pliocene } \\
\text { sediments }\end{array}$ \\
\hline \multirow{7}{*}{ 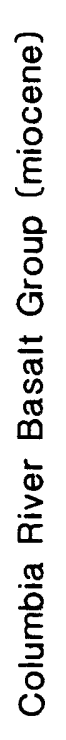 } & \multirow{6}{*}{ 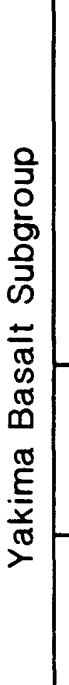 } & \multirow{4}{*}{$\begin{array}{l}\text { Saddle } \\
\text { Mountains } \\
\text { Basalt }\end{array}$} & Pomona Member & \multirow{6}{*}{$\begin{array}{r}\text { Miocene } \\
\text { sedimentary } \\
\text { rocks } \\
\text { (Ellensburg } \\
\text { and Latah } \\
\text { Formations) } \\
\text { (fluvial, } \\
\text { lacustrine, } \\
\text { and } \\
\text { volcaniclastic } \\
\text { materials) }\end{array}$} \\
\hline & & & $\begin{array}{l}\text { Pomona-Umatilla interbed } \\
\text { (informally called Selah interbed } \\
\text { now included in Beverly Member } \\
\text { of Ellensburg Formation) }\end{array}$ & \\
\hline & & & Umatilla Member & \\
\hline & & & $\begin{array}{l}\text { Saddle Mountains-Wanapum interbed } \\
\text { (informally called Mabton interbed } \\
\text { of Ellensburg Fomation) }\end{array}$ & \\
\hline & & $\begin{array}{l}\text { Wanapum } \\
\text { Basalt }\end{array}$ & Wanapum-Grande Ronde interbed & \\
\hline & & $\begin{array}{l}\text { Grande } \\
\text { Ronde } \\
\text { Basalt }\end{array}$ & of Ellensburg Formation & \\
\hline & & \multicolumn{3}{|c|}{ Basalts (pre-Yakima Basalt Subgroup) } \\
\hline & & \multicolumn{3}{|c|}{ Basement rocks (pre-Columbia River Basalt Group) } \\
\hline
\end{tabular}

FIGURE 2.--Generalized stratigraphy of the Columbia Plateau (from Drost, B. W., and Whiteman, K. J., 1986, Surficial geology, structure, and thickness of selected geohydrologic units in the Columbia Plateau, Washington: U.S. Geological Survey Water-Resources Investigations Report 84-4326). 


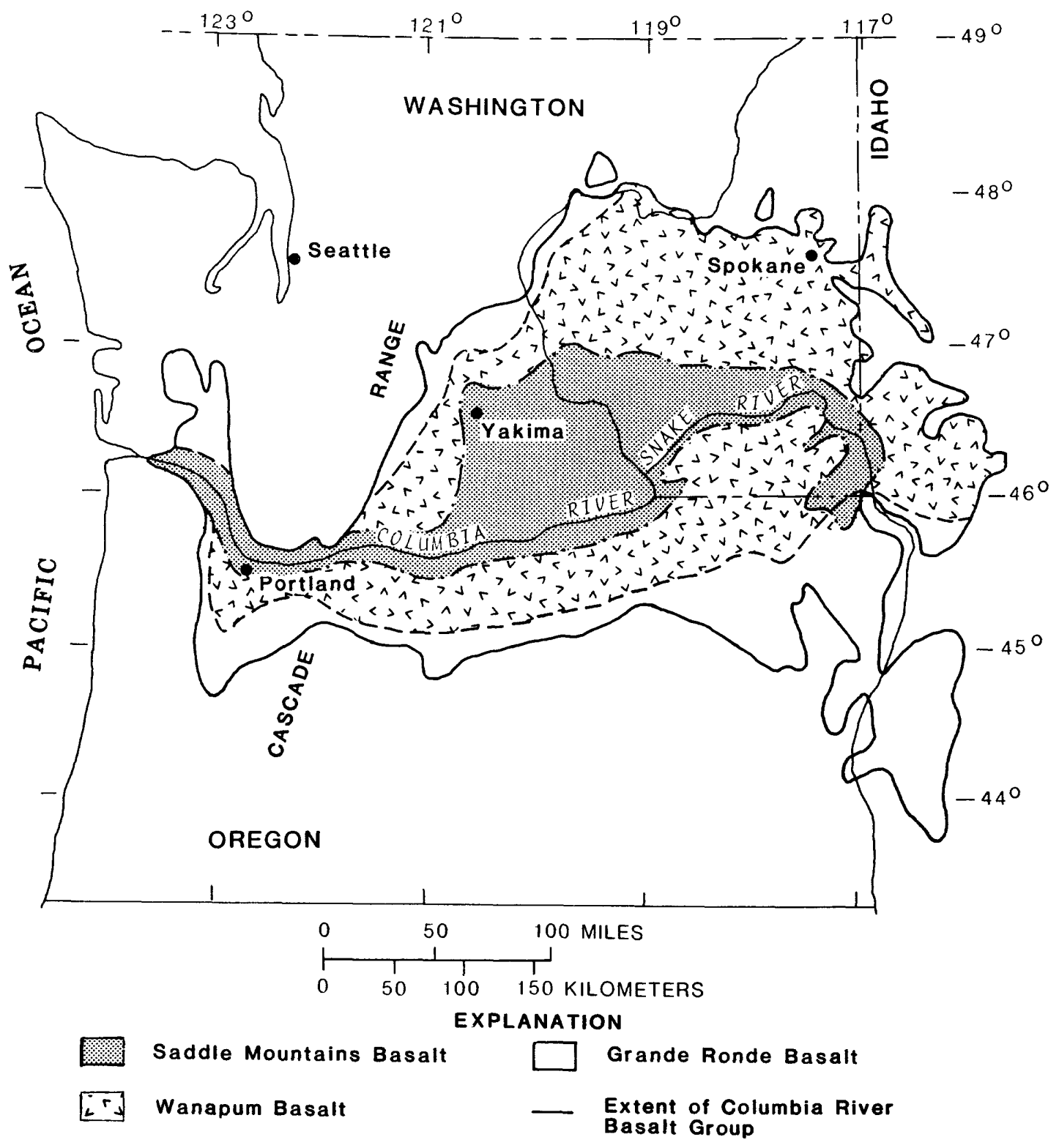

FIGURE 3.--Extent of Columbia River Basalt Group and its three major formations. 


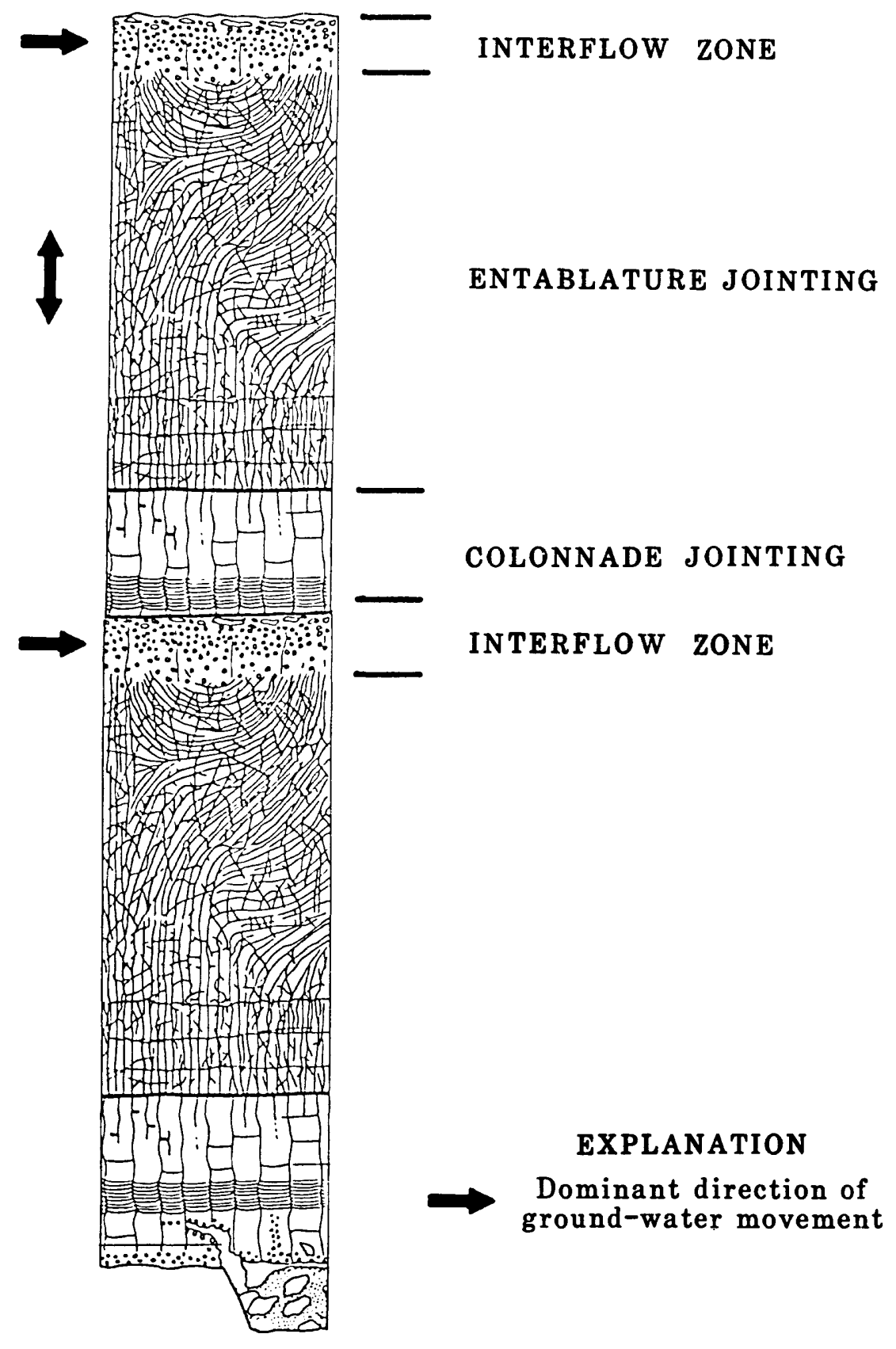

FIGURE 4.--Generalized diagram of a typical flow in the Columbia River Basalt Group. 


\section{$\underline{\text { Aquifer System }}$}

The regional ground-water system in the study area is a multi-aquifer system. The more permeable interflow zones (fig. 4) act as semiconfined aquifers that are hydraulically connected through the entablature and colonnade zones. The lateral hydraulic conductivities are generally greater in the interflow zones than in the other zones, and ground-water movement is generally lateral. The regional multi-aquifer system has been conceptualized as consisting of three major aquifers, one each in the Saddle Mountains, Wanapum, and Grande Ronde Basalts. Each aquifer contains several interflow zones. In this conceptual model the sedimentary beds that lie between the basalt formations, rather than the entablature and colonnade zones, are regarded as the confining units.

The Saddle Mountains aquifer is an unconfined aquifer that is recharged from precipitation and percolation of irrigation water. The Wanapum and Grande Ronde aquifers are semiconfined toward the center of the basin and unconfined at their margins. They are recharged by continuous leakage from overlying formations where semiconfined. On a regional scale, ground water moves horizontally from the recharge areas tow ard topographic lows (river valleys and coulees). The general movement is toward the Columbia River, the largest continuous topographic low. There are numerous subregional ground-water flow systems such as those in the Walla Walla basin, the Yakima River basin, the Quincy basin, and the Umatilla basin.

In recharge areas hydraulic head decreases with depth and in discharge areas hydraulic head increases with depth near the major rivers (Brown, 1978; D.B. Sapik and H. H. Bauer, written commun., 1983; F. A. Packard, written commun., 1983; A. D. Smith, written commun., 1983). Larger head changes with depth are probably due to confining effects of fairly continuous regional basalt flows or interbeds, or both. Vertical movement of water between formations is continuous; the amount of movement depends on the vertical hydraulic conductivity of interbeds and the head differences across this semiconfining layer. Interbeds can be an aquifer or a confining bed; how ever, most act as a leaky confining bed. Vertical conductivity of interbeds is reported to range from 1 to $\mathbf{0 . 0 0 1}$ foot per day (D. B. Sapik and H. H. Bauer, written commun., 1984; Mac Nish and Barker, 1976).

The structural setting of the Columbia Plateau is complicated. Many major faults, anticlines, monoclines, synclines, and dikes are present. Structural deformation in the plateau has had a wide range of effects on ground-water movement. In some areas ground-water movement has been dammed or slowed either by direct deformation of basalt flows or by the enhancement of secondary mineralization along faults (Newcomb, 1969). In some areas, deformation has provided an increased potential for the vertical movement of water through additional fracturing and increasing the interconnectedness of fracture assemblages. 
Transmissivity of the formations averages about $10,400 \mathrm{ft}^{2} / \mathrm{d}$, with areal variations on the order of 1,000 to $50,000 \mathrm{ft}^{2} / \mathrm{d}$ (Luzier and Burt, 1974; Tanaka, Hansen, and Skrivan, 1974; Mac Nish and Barker, 1976; U.S. Geological Survey, 1975; Prych, 1983). Irrigation and municipal wells generally obtain water from the shallowest basalt formation; however, in many places, wells are completed in both the uppermost formation and a lower formation in order to obtain an adequate water supply. Where the uppermost formation, usually the Wanapum Basalt, is heavily developed, large-capacity wells are now being completed in the Grande Ronde Basalt, and are cased through the upper units. Domestic wells generally tap the surficial silt, sand, gravel, and clay where they are of sufficient thickness to provide an adequate yield. For example, in the Quincy basin an adequate domestic ground-water supply is available from the outwash and alluvial deposits. However, numerous domestic wells pump from the basalt aquifer.

The basalt ground-water system supplies about 1.8 million acre-feet of water annually for the irrigation of about 500,000 acres of land. This is about one-fifth of the total water used to irrigate about 2.5 million acres of croplands in the study area (Pacific Northwest River Basins Commission, 1971; 1981). 


\section{Surface Water}

The three largest sources of surface water for irrigation on the plateau are the Columbia, Snake, and Yakima Rivers. The Columbia River provides about 2,300,000 acre-feet of water to about 520,000 acres in the U.S. Bureau of Reclamation's Columbia Basin Irrigation Project and also provides water for numerous croplands along the length of the river. The Snake River and its tributaries provide about 390,000 acre-feet to about 130,000 irrigated acres in the study area, and the Yakima River provides about 2,500,000 acre-feet to about 600,000 acres.

The Deschutes, Umatilla, John Day, and Walla Walla Rivers are also important sources of water for irrigation. Annual diversion from these rivers is about $1,800,000$ acre-feet, which is used to irrigate 620,000 acres. About 249,000 acres of the irrigated lands are in the Deschutes River basin, and the 1,225,000 acre-feet used to irrigate these lands is diverted from outside the study area. About 16,000 acres, for which 59,000 acre-feet (the smallest quantity per acre used of the above four sources) are provided, lies in the Walla Walla River basin.

The hydrology of the surface-water system and the use of it for irrigation is important for understanding the regional ground-water system. The major rivers discussed above are all considered to be drains for the ground-water system. Several of the rivers have completely cut through one or two of the formations. Furthermore, numerous lakes in the northern part of the study area act as a control on the ground-water movement in the uppermost basalt formation. An understanding of the ground-water and surface-water relations and the variability of these relations will greatly enhance the understanding of the movement of water in the basalts.

The application of surface water for irrigation has caused rising water levels in both the basalts and the overlying sedimentary material. This artificial recharge has both positive and negative effects. The rising water levels have caused waterlogging in some locations, but they have also resulted in additional ground-water supplies. The response of the water levels in the basalts, to both the artificial recharge and the damming of rivers, should supply valuable information. 


\section{WATER PROBLEMS}

Surface-water withdrawals, excluding the Columbia Basin Irrigation Project, are nearly all allocated. Thus, if all or part of the remaining 3 million acres of irrigable land in the study area is to be irrigated, ground water will be the major source. The effects of major increases in ground-water withdrawals have been studied only in small areas, however, and cannot be evaluated on a regional scale until a better understanding of the ground-water flow system is obtained. Expanded ground-water development will probably occur in the deeper basalts, and this development has the potential to create water-level declines in the shallower system and to reduce streamflow in the region. The possibility also exists of withdrawing water of poorer quality.

Current problems on the Columbia Plateau include large rises in ground-water levels owing to canal leakage and deep percolation of irrigation water in the Columbia Basin Irrigation Project and in the Yakima River basin. These ground-water rises have resulted in waterlogging problems in some areas. On the other hand, in areas of heavy ground-water withdrawals, mainly the Odessa-Lind area of central Washington and the Umatilla and The Dalles area of northern Oregon, large declines in water levels have occurred. The total effect of existing or increased ground-water pumpage and surface-water utilization has not been studied on a regional scale.

An associated problem involves the Department of Energy's Basalt Waste Isolation Project, which addresses the feasibility of burying high-level nuclear wastes in basalt. Studies of the regional ground-water flow system are needed to better understand rates and directions of ground-water movement and changes that might be induced into the hydrologic system because of continued use of this resource. The disposal of high-level wastes is a crucial issue to the Columbia Plateau, the State, the northwest, and the Nation. 
The purpose of this study is to obtain a better understanding of the regional ground-water system underlying the Columbia Plateau. To achieve this purpose, the following objectives have been defined:

1) Describe the geologic framework of the regional aquifer system. This includes the areal extent and thickness of the three major aquifer units, the hydrologically important interbeds, the surficial glacial-alluvial system, and the major geologic controls, such as faults and anticlines.

2) Describe the geohydrologic characteristics of the regional system. This includes hydraulic properties, stream-aquifer relations, and selected potentiometric surfaces as they were under natural conditions, as they exist today, and as they might be in the future.

3) Describe the water budget of the regional aquifer system underlying the Columbia Plateau.

4) Describe the geochemical framework. The geochemical framework will include developing a geochemical model and verification of this model. The model will then be related to the ground-water flow system. This will assist in determining sources of recharge and the direction and rate of ground-water flow.

5) Develop a data-base management and application system for hydrologic and geologic data.

6) Develop a regional ground-water flow model as a tool for investigating the sensitivity of the ground-water system to hydraulic characteristics, and the hydrologic impacts of hypothetical future development. The model will be used to analyze movement of water into, within, and out of the aquifer system with respect to changes from pre-development to present-day conditions (man-induced changes to the natural system), and from existing to hypothetical future conditions. 


\section{SCOPE AND APPROACH}

\section{Geologic Framework}

Regional structure-contour and isopach maps of the Saddle Mountains, Wanapum, and Grande Ronde Basalts will be prepared, as will structure-contour, isopach, and lithology maps of the Mabton interbed and the Vantage Member of the Ellensburg Formation. The work will incorporate published structure contour and geologic maps for most of the Columbia Plateau in Washington (Swanson and others, 1979a, 1979b), and results from current ground-water studies in the Umatilla River basin in Oregon and Horse Heaven Hills area in Washington (A. D. Smith, written commun., 1983; F. A. Packard, written commun., 1983). The work will be coordinated with a current Washington District project (the distribution of dissolved sodium in the ground water of the Columbia River Plateau, Washington), which has as one of its objectives the definition of the geologic framework of that part of the Columbia Plateau basalt aquifer system in Washington State. All well sites used in defining the geologic framework will be updated and verified in the U.S. Geological Survey GWSI system. Chemical analysis of core chips will be completed to help in the identification of formation horizons in areas that are geologically complex.

Several geohydrologic problems will be addressed within the geologic framework through identification and mapping. These are:

1. How do faults affect ground-water movement?

2. What is the nature, location, and effect of "barriers" on ground-water movement?

3. How do anticlines affect the movement of ground water?

4. Can stratigraphic correlations of flow units be made?

5. What is the relation between basalt and basement rock at margins? 
Flow system.-Four mass ground-water-level measurements are planned during the course of the study. All well sites identified and used as measurement points will be coded for the geohydrologic units, field checked for additional information, and updated or input into the GWSI system. Potentimetric maps of the three studied basalt formations and the overlying sedimentary material will be prepared and published. These maps will be used in conjunction with the geologic maps to define ground-water flow boundary conditions for the proposed numerical model.

Hydraulic characteristics.--Initial estimates will be made of hydraulic characteristics for each major formation and interbed. Estimations will be based on previous studies, geologic information, specific-capacity data, water-level-change data in response to pumping, and model analyses. A method for interpolating point-data values to model grid points will be determined. The inherent anisotropy and heterogeneity of the basalts precludes contouring of vertical and lateral conductivities. However, zonation of leakage and storage coefficient values will be attempted. Variation of the storage coefficient with depth will be analyzed. The streambed and lakebed leakage coefficients will be initially estimated based on previous studies, analysis of hydraulic head variation, and the vertical conductivity. Additional problems that will be addressed are:

1. What is the comparison of vertical hydraulic conductivities of interbeds and flow in teriors?

2. How is the storage coefficient of the shallow unconfined basalts estimated?

3. How do formational hydraulic conductivities near outcrops compare to formational hydraulic conductivities near the basin center?

4. How does one account for interbeds, flow margins of individual flows, areal variations in fractures, and analysis of well test data from wells with different depths of penetration when mapping hydraulic conductivities?

Stream-aquifer relations.--Base flow in major streams and streambed leakage coefficients will be estimated, gaining and losing stream reaches will be defined, and aquifers across which streams flow will be identified.

The stream system as it existed before development will be described. Stream-elevation changes that occurred due to dams and reservoirs will be located by latitude and longitude, and streambed leakage coefficients will be analyzed to determine if these values have changed due to the structures.

Because lack of streamflow gaging sites, however, the approach for the stream-aquifer relations will involve sensitivity analysis and qualitative estimates. Also, because the major streams such as the Columbia, Snake, and Yakima Rivers are large, most conventional techniques used to estimate aquifer discharge would not be valid. Therefore, through the ground-water model and sensitivity analysis, there exists the opportunity to define the aquifer discharge to streams for the first time on a regional scale and to obtain a better understanding of the hydrology of streams and the ground-water system in the shallow basalt. 


\section{Water Budget}

The description of the water budget will focus mainly on recharge, pumpage, and ground-water movement at boundaries. Due to the semiarid environment of most of the plateau, the scope of this objective will include the development of a comprehensive daily regional recharge model. This model will account for the major components of and factors affecting recharge and will be based on published watershed and rangeland models. Previous studies on the Columbia Plateau (H. H. Bauer, written commun., 1983) have shown that estimates of recharge should be done on a daily basis. The model will address the following items: soil properties, potential evapotranspiration, potential/actual transpiration, potential/actual evaporation, precipitation, temperature, snowpack accumulation and melting, land use, interpolation of meteorological variables, calculation of solar radiation, surface runoff, root growth for all land uses, and foliar cover evaporation. Calculations will be done over discrete areal blocks (less than 1 square mile) for most of the area with irrigated agriculture and for areas (watersheds) which have streamflow data. Calculations will be completed for pre-development and current conditions. Final estimates will be based on 20 years of meteorological data. This effort involves a large expenditure of manpower and time, but estimation of ground-water discharge is nearly impossible. Furthermore, meaningful ground-water model simulation requires estimates of recharge. Also, the RASA project will provide the recharge estimates for the subregional model being developed for the Basalt Waste Isolation Project that is studying in more detail the proposed high-level nuclear waste repository site.

Ground-water and surface-water irrigation withdrawal rates and irrigation application rates will be estimated, plotted by location, digitized, and incorporated in a data base system. The recharge model will then access this data base to include the application rates with daily precipitation quantities.

\section{Geochemical Framework}

An ongoing Washington District project has as its objectives a description of the geologic framework, ground-water flow system, and geochemistry and water quality of the Columbia River Basalt Group in Washington State, especially with respect to the origin and spatial definition of the sodium cation. RASA project personnel will coordinate their efforts with this project in fiscal years 1983 and 1984. Results of the sodium project will be incorporated, updated, and verified within the regional framework of this RASA study in 1985 and 1986. 
Data-base systems that will be used are (1) the Geological Survey WATSTORE system, (2) the Geological Survey System 2000 Ground-Water Site Inventory, (3) a system for gridded data, (4) a system for non-gridded data, and (5) a model array management system.

Systems (1) and (2) will be for storage, retrieval, and updating of pertinent streamflow, climate, and ground-water data. System (3), which will be based on the work of either Luckey and Ferrigno (1982) or Kontis and Mandle (1980), will be used for the storage and application of geologic, hydrologic, and land-use aspects for gridded data. This system will be used for the formation of model arrays and also as a regional data base in the future. The non-gridded data system (4) will be used to help for $m$ the gridded data system (3). The model array management system (5) will store and input model data for transmissivity, leakage and storage coefficients, and head matrices. The program will be designed to allow for parameter changes at node locations and the zonation of nodes in areas having similar hydraulic characteristics.

\section{$\underline{\text { Regional Digital Ground-Water Flow Model }}$}

The model effort will be started in fiscal year 1984 or 1985 with the determination of the model to use in developing one large scale but small block model. Findings of previous and ongoing model studies (D. B. Sapik and H. H. Bauer, written commun., 1983; W. Meyer, written commun., 1983; P. A. Smith, oral commun., 1983; A. J. Hansen and others, written commun., 1984) will be used in this work element. Conceptually, the regional movement of water, both vertically and laterally, is in major aquifers which are in hydraulic connection.

A previous study (F. A. Packard, written commun., 1984) has shown the importance of structure and the areal extent of geologic units on ground-water movement. Another previous study (D. Sapik, written commun., 1983) concluded that the geologic framework and definition of the flow system are important prerequisites to modeling. Thus, this study will focus initially on those aspects. Results will then be used to define the regional model-grid system. The grid system will orient to structure, surface-water bodies, river valleys, and areal extent of formations. Boundary conditions will be oriented to early stated ones; this can be accomplished by modeling the complete system and not using artificial or river boundaries.

Analysis of water-level changes from spring 1983 to spring 1985 will determine whether calibration will be completed for pre-development conditions or for time-averaged conditions of 1983 to 1985. A transient model calibration will probably be attempted; however, the need for an accurate time history of pumpage and recharge estimates might preclude a transient simulation. 
The major work elements are given in the following outline, and estimated time lines for the elements in figure 5.
I. Staffing
II. Work plans
Will be reviewed at the beginning of each fiscal year

III. Geologic framework

A. Evaluate existing data

B. Develop data management system, which includes GWSI

C. Compile existing data

D. Identify, compile, interpret well logs - input to GWSI

E. Compile and evaluate geophysical data

F. Map extent of major formations

G. Map extent of major in terbeds

H. Map major streams/lakes with respect to geologic unit

I. Define geologic boundary conditions

1. Pinchouts

2. Faults

3. Outcrops

J. Reevaluate preliminary work on water-level and geochemistry data

K. Finalize interpetation of geologic framework

L. Write report defining geologic framework

IV. Flow system

A. Evaluate adequacy and completeness of existing water-level control data

B. Develop data management system, GWSI, and point-data base (DBM)

C. Choose observation well network

1. Conduct five mass water-level measurements

2. Refine network after each round of measurements, and expand as new wells are drilled

D. Plot and interpret water levels, study vertical variations

E. Define flow boundary conditions on the basis of geology and water-level data

F. Define ground water-surface water relations

V. Hydraulic properties

A. Evaluate existing data

1. Map hydraulic conductivity, transmissivity, leakage coefficients (interbed, canals, streams), and storage coefficients from previous studies

2. Reevaluate data after additional computations and preliminary model results become available

B. Develop data management system

1. GWSI-SYSTEM 2000

2. Data base management for point, gridded, and contoured data (DBM)

C. Compile aquifer specific-capacity tests, data on porosity, and specific yield

D. Map hydraulic conductivity

E. Map transmissivity

F. Map lake/stream/canal leakage coefficients

G. Map storage coefficients 


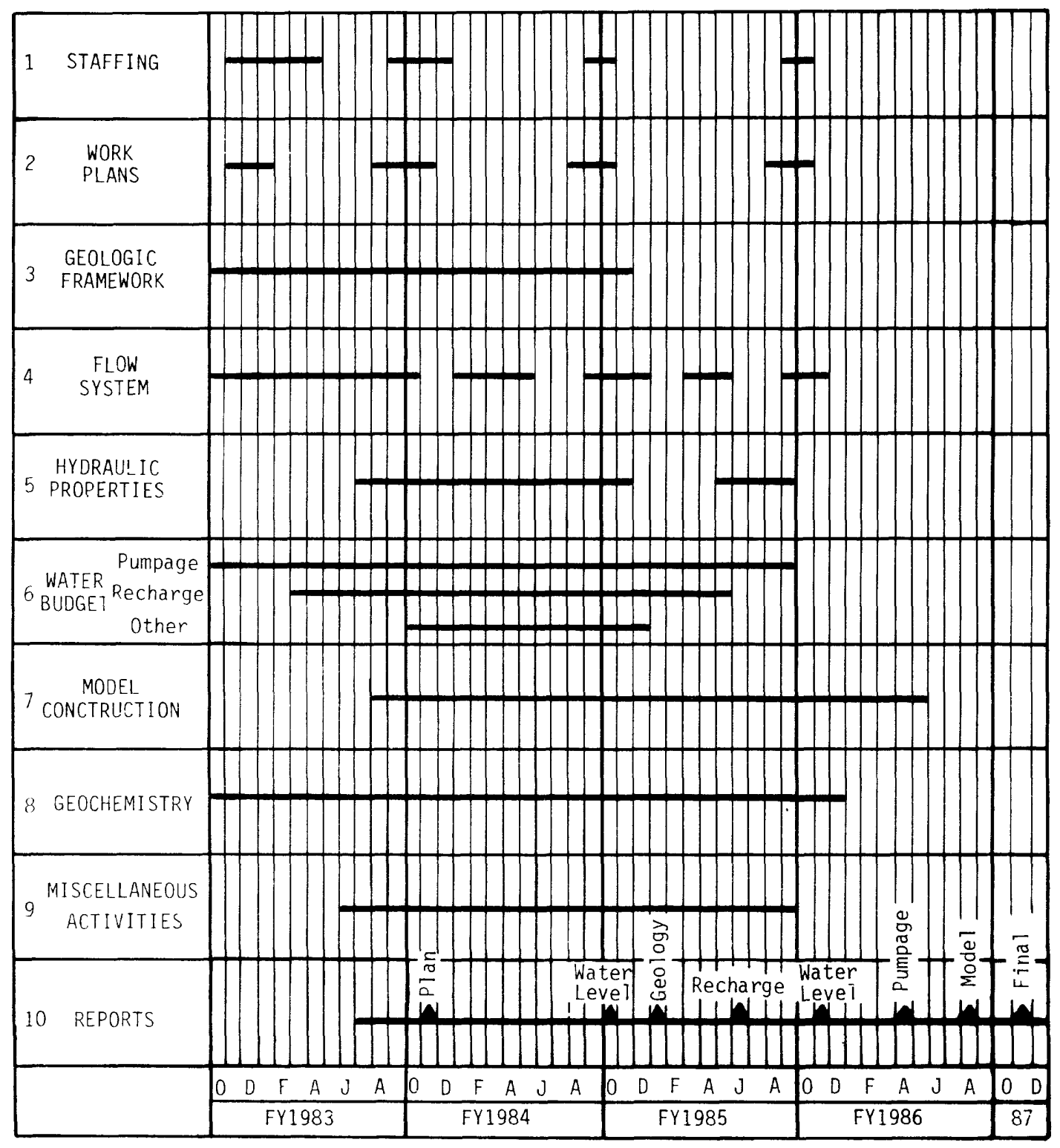

FIGURE 5.--Time lines for major work elements of the Regional Aquifer System Analysis of the Columbia River Basalt aquifer system. 
VI. Water budget

A. Estimate ground-water pumpage, distribution, and annual and monthly rates

1. Irrigation (GWSI-DBM)

2. Municipal (GWSI-DBM)

3. Domestic (DBM)

B. Estimate surface-water pumpage, distribution, and rates

C. Estimate irrigation application rates and distribution

1. Ground water, by crop

2. Surface water, by crop

D. Determine canal distribution systems

1. Inflows

2. Outflows

3. Leakage

4. Return flows

5. Efficiency

E. Define for lakes

1. Geologic unit

2. Average altitudes

3. Altitude changes

4. Leakage

F. Define for streams

1. Geologic unit

2. Average altitude (stream head) and location for every 5- to 10-foot-stage change or within accuracy of published topographic maps

3. Dam altitude, average pool altitude, and changes in stage through a year

4. Base flow - perennial

5. Runoff - ephemeral, calculate runoff using maximum infiltration rates, precipitation, and evapotranspiration relations and compare on monthly and annual basis with published and calculated runoff volumes

6. Compile available data on pre-development stream system

G. Compile soil map data

1. Type, distribution and depth

2. Water-holding capacity

3. Infiltration rates and variation of rates with moisture content

H. Compile daily precipitation data, 1956 to 1978

1. Store data, WATSTORE

2. Extend records, SAS, WATSTORE, interpretation

3. Interpolate on daily basis to model grid points

4. Store data (DBM)

I. Compile maximum-minimum temperature data, 1956 to 1978

1. Same as H. above 
J. Map land use (vegetation type) - based on previous studies, remote imagery processing, and fieldwork

1. Forest lands

2. Irrigated lands

a. Crop map

(1) Rooting depths and distribution with time

(2) Growing season (phenological state)

(3) Consumptive-use factors

3. Dryland croplands

4. Rangeland

a. grass

b. sage

K. Estimate potential evapotranspiration (PET)

1. Review methods, decide on suitable one based on existing data

2. Test methods

3. Make final choice of PET method

L. Estimate actual evapotranspiration (AET)

1. Determine PET/AET relations for three major soils in Columbia Plateau and for major vegetation types

M. Develop recharge model (daily)

1. Conceptualize

2. Develop numerical model include items A-L above

3. Test model

4. Make field measurements of evaporation, runoff, soil moisture, temperature, and precipitation

5. Make sensitivity analysis

6. Make error analysis

7. Operate recharge model; output results on a grid network (DBM)

8. Write report on recharge model

VII. Ground-water flow model construction

A. Delineate boundaries

B. Discretize study area into a ground-water flow model grid system

1. Use defined boundaries

2. Incorporate surface-water bodies

3. Account for major geologic structures and stratigraphy

4. Determine future model use and access data base

C. Delineate model layers

1. Base on results from geologic framework

2. Include, at minimum, three major aquifers and two major interbeds

3. Decide on technique for including interaction with surficial sedimentary system

4. Determine if Grande Ronde Basalt should be subdivided into two layers

D. Develop data-base management system, conjunctively with point data

E. Compile-compute-define boundary conditions

1. Pool district staff knowledge

2. Determine constant heads, no flows, and peripheral area inflows 
F. Construct preliminary ground-water flow model

1. Put software on district Prime system and modify as necessary

2. Use DBM for model input parameters

3. Test preliminary model

a. Sensitivity analysis

b. Data-base evaluation

G. Construct simplified cross-sectional model of a flow path if manpower and time constraints allow

1. Base on preliminary model results

2. Study vertical head variations and variations in parameters across confining beds

H. Refine preliminary ground-water flow model

1. Base on preliminary model effort

2. Update, change, evaluate, and collect new data

I. Calibrate ground-water flow model

1. Choose between manual/automatic parameter estimation

J. Test for potential for simulating pre-development conditions

K. Operate for management alternatives

L. Interpret flow-model results

M. Write report describing model results

1. Pre-development conditions

2. Calibrated (present conditions): evaluation of error, evaluation with respect to conceptual geohydrologic and geochemical models

3. Management alternatives (hypothetical future conditions)

4. Compare 1-3 above

5. Evaluate 3 above

VIII. Geochemistry

A. Compile and collect water-quality data for study area

1. Previous data compiled and studied (G. Bortleson, oral commun., 1983; J. Gonthier, oral commun., 1983)

2. Washington part of chemical-geochemical data is being collected (G. Bortleson, oral commun., 1983)

3. Oregon part of chemical-geochemical data will be collected in 1984 and 1985

B. Analyze data

1. Update Washington State office chemical-geochemical study of Columbia Plateau (sodium study)

2. Work with project staff of a previous water-quality study

C. Develop geochemical model of water-rock reactions

1. Extend sodium study results into Oregon and incorporate into modeling framework

2. Collect more data if necessary

D. Refine geochemical model using new water-quality data

E. Interpret results of geochemical model with respect to the ground-water flow system

F. Write report on geochemistry

IX. Miscellaneous activities

A. Conduct public meetings (Washington and Oregon)

B. Define regional management alternatives, hypothetical future conditions

X. Document results through the report process 


\section{REPORTS}

Results of this study will be presented in a series of Water-Resources Investigations Report (WRIR) books and maps that will be completed during the study. The reports will describe various parts of the study, and a Professional Paper will summarize final study results.

Reports to be completed during the study will include:

\section{$\underline{\text { Subject }}$}

1. Geologic framework

2. Recharge model documentation

3. Estimates of recharge

4. Digital model analysis

5. Potentiometric surface maps

6. Ground-water pumpage

7. Water-quality characteristics
Type

WRIR-map
WRIR-book
Book
Book
Map
Map
Map

The Professional Paper will consist of four chapters, including a summary appraisal of the Columbia River Basalt Group underlying the Columbia Plateau in the study area. The report will address the following topics:

1. Geohydrologic framework of the Columbia River Basalt aquifer system.

2. Hydrology of the Columbia River Basalt aquifer system, including model results.

3. Geochemistry of the Columbia River Basalt aquifer system.

4. Summary appraisal of the Columbia River Basalt aquifer system. 


\section{REFERENCES}

Brown, J. C., 1978, Discussion of geology and ground-water hydrology of the Columbia Plateau, with specific analysis of the Horse Heaven, Sagebrush Flat, and Odessa-Lind Areas, Washington: Washington State University, College of Engineering, Res. Report 78/15-23, 51 p.

Kontis, A.L., and Mandle, R. J., 1980, Data-base system for Northern Midwest Regional Aquifer-System Analysis: U.S. Geological Survey Water-Resources Investigations Report 80-104, 23 p.

Luckey, R. R., and Ferrigno, C. F., 1982, A data-management system for areal interpretive data for the high plains in parts of Colorado, Kansas, Nebraska, New Mexico, Oklahoma, South Dakota, Texas, and Wyoming: U.S. Geological Survey Water-Resources Investigations Report 82-4072, 11 p.

Luzier, J. E., and Burt, R.J., 1974, Hydrology of basalt aquifers and depletion of ground water in east-central Washington: Washington Department of Ecology Water-Supply Bulletin 33, 53 p.

MacNish, R.D., and Baker, R.A., 1976, Digital simulation of a basalt aquifer system, Walla Walla River basin, Washington and Oregon: Washington Department of Ecology Water-Supply Bulletin 44, 51 p.

Newcomb, R. C., 1969, Effect of tectonic structure on the occurrence of ground water in the basalt of the Columbia River Group of the Dalles area, Oregon and Washington: U.S. Geological Survey Professional Paper 383-C, $33 \mathrm{p}$.

Pacific Northwest River Basins Commission, 1971, Columbia-North Pacific Region Comprehensive Framework Study, Appendix IX, Irrigation: Vancouver, Wash. (P.0. Box 908) 347 p.

Pacific Northwest River Basins Commission, 1981, Irrigated 1ands in the Pacific Northwest, 1980: Vancouver, Wash. (P.0. Box 908), 30 p.

Prych, E. A., 1983, Numerical simulation of ground-water flow in lower Satus Creek basin, Yakima Indian Reservation, Washington: U.S. Geological Survey Water-Resources Investigations Report 82-4065, 78 p.

Swanson, D. A., and Wright, T. L., 1978, Bedrock geology of the northern Columbia plateau and adjacent areas: in V. R. Baker and D. Nummedal, eds, The Channeled Scablands: Office of Space Science, NASA, Chapter 3, p. 37-57.

Swanson, D. A., Anderson, J. L., Bentley, R. D., Byer1y, G. R., Cap, B. E., Gardner, J. N., and Wright, T. L., 1979a, Reconnaissance geologic map of the Columbia River Basalt Group in eastern Washington and northern Idaho: U.S. Geological Survey Open-File Report 79-1363, 26 p., 12 sheets. 
Swanson, D. A., Brown, J. C., Anderson, J. L., Bentley, R.D., Byerly, G. R., Gardner, J. N., and Wright, T. L., 1979b, Preliminary structure contour maps on the top of the Grande Ronde and Wanapum Basalts, eastern Washington and northern Idaho: U.S. Geological Survey Open-File Report 79-1364, 2 sheets.

Swanson, D. A., Wright, T. L., Hooper, P. R., and Bentley, R. D., 1979c, Revisions in stratigraphic nomenclature of the Columbia River Basalt Group: U.S. Geological Survey Bulletin 1457-G, 59 p.

Tanaka, H. H., Hansen, A. J., and Skrivan, J. A., 1974, Digita1-mode1 study of ground-water hydrology, Columbia Basin Irrigation project area, Washington: Washington Department of Ecology Water-Supply Bulletin 40, $60 \mathrm{p}$.

U.S. Department of the Interior, 1975, Water resources of the Toppenish Creek basin, Yakima Indian Reservation, Washington: U.S. Geological Survey, Water Resources Investigations Report 42-74, 144 p. 